\title{
The use of sperm whale ivory in Chalcolithic Portugal
}

\section{La utilización de marfil de cachalote en el Calcolítico de Portugal}

\author{
Thomas X. Schuhmacher $(*)$ \\ Arun Banerjee (**) \\ Willi Dindorf $(* * *)$ \\ Chaturvedula Sastri $(* * * *)$ \\ Thierry Sauvage $(* * * * *)$
}

"Our captain stood upon the deck,

A spy-glass in his hand, A viewing of those gallant whales That blew at every strand.

Oh, your tubs in your boats, my boys, And by your braces stand, And we'll have one of those fine whales, Hand, boys, over hand!

So, be cheery, my lads! may your hearts never fail! While the bold harpooner is striking the whale!"

H. Melville, Moby Dick, Ch. 39.
"Skallagrim was also a great shipwright. There was plenty of driftwood to be had west of Myrar, so he built and ran another farm at Alftaness and from there his men went out fishing and seal-hunting, and collecting the eggs of wild fowl, for there was plenty of everything. They also fetched in his driftwood.

Whales often got stranded, and you could shoot anything you wanted, for none of the wildlife was used to man and just stood around quietly."

Egil's saga, Ch. 29 (translation H. Pálsson and P. Edwards, Penguin Classics 1976).

\begin{abstract}
Scientific analysis were undertaken within a research project concerning ivory objects from the Chalcolithic to Early Bronze Age of the Iberian Peninsula. In several of the analyses of objects from Portuguese Estremadura, especially V-perforated buttons, we could detect for the first time the presence of sperm whale ivory. This highlights the advantage and necessity of scientific analysis of ivory. It also clearly demonstrates that not all ivory used was ivory from African or Asian elephants, but we also did find ivory from the extinct Elephas antiquus, the hippopotamus and in this case sperm-whale. Thus, already in the Chalcolithic the raw material provenience was highly diverse, which in the absence of scientific analysis might lead to an erroneous interpretation of prehistoric exchange networks. Different methods, including optical microscopy, measurement of hardness and specific gravity, Micro-Raman Spectroscopy, elemental analysis and Isotopic Ratio Mass Spectrometry have been applied. In this paper we present these methods and the results, and we discuss about the implications of these results for the reconstruction of prehistoric economy and life in this
\end{abstract}


region. Finally, taking into account the natural conditions as well as prehistoric and historic data of whale hunting and scavenging of beached animals, we conclude that the most plausible explanation for the presence of sperm whale ivory in Chalcolithic Portugal is the use of the teeth obtained from stranded animals. This interpretation is possible because of the human populations using this ivory are those living close to the sea and exploiting among others- marine resources.

\section{RESUMEN}

En el marco de un proyecto de investigación sobre objetos de marfil del Calcolitico al Bronce Antiguo en la Península Ibérica efectuamos análisis cientificos. En varios de los objetos de la Estremadura portuguesa, en especial en los botones con perforación en $V$, detectamos por primera vez la presencia de marfil de cachalote. Así se demuestra claramente la ventaja y la necesidad de efectuar análisis cientificos del marfil. No todo el marfil utilizado provenía de los elefantes africanos y asiáticos. Además encontramos marfil del desaparecido Elephas antiquus, de hipopótamo, y en este caso de cachalote. Así ya en el Calcolitico el origen de la materia prima era muy diverso, lo que en ausencia de análisis cientificos puede conducir a una errónea interpretación de las redes prehistóricas de intercambio. Los métodos empleados fueron la microscopia óptica, la medición de la dureza y del peso específico, la espectroscopía Micro-Raman, el análisis elemental y la espectrometría isotópica de masas. En este trabajo presentamos estos métodos y los resultados. Además discutimos sus consecuencias para la reconstrucción de la economía y la vida de las sociedades prehistóricas de la región. Teniendo en cuenta las condiciones naturales y los datos prehistóricos e históricos sobre la caza de ballenas y el aprovechamiento de animales varados consideramos que la explicación más plausible de la presencia de marfil de cachalote en el caso del Calcolítico portugués es el uso de dientes de cachalotes varados. Cabe esta interpretación dado que las poblaciones que emplean este marfil son las que viven cerca del mar explotando, entre otros, los recursos marinos.

Key words: Chalcolithic Early Metal Age; Portuguese Estremadura Western Mediterranean; Ivory Bone like materials; Sperm whale; Sea mammals; Scientific analysis; Optical microscopy; Micro-Raman Spectroscopy, Elemental analysis; Isotopic Ratio Mass Spectometry.

Palabras clave: Calcolitico Primera Edad de los Metales; Estremadura portuguesa Mediterráneo occidental; Marfil Hueso; Cachalote; Mamíferos marinos; Análisis científicos; Microscopia óptica; Espectroscopía Micro-Raman; Análisis elemental; Espectroscopía isotópica de masas.

\section{HISTORY OF INVESTIGATION}

As early as the late $19^{\text {th }}$ century, Estácio da Veiga (1886: 268-270, 1887: 212) proposed that finished ivory objects found on Bronze Age sites from the Iberian Peninsula, as well as the raw material itself, were imported from Northern Africa (Fig. 1). But since that study, little work had been done on the inventory of ivory objects in Portugal. In their monumental work on the megalithic tombs of the Iberian Peninsula, G. and V. Leisner (1943: 474-475) included a list of the ivory objects from the southern part of the peninsula. Later, Harrison and Gilman (1977) produced an updated inventory list of ivory objects known from bibliographic sources. They and others in subsequent publications elaborated upon specific studies of the relations between the Iberian Peninsula and Northwest Africa during the Bell Beaker period (Poyato and Hernando 1988). Since that time, only a few regional works have been published, among which are those of Spindler (1981) for Portugal. Finally Cardoso (2003) published several ivory objects found during his excavation in the settlement of Leceia (Oeiras, Portugal).

In a broader research project, we attempted to compile a new catalogue, as complete as possible, of all ivory objects from the Iberian Peninsula dated from the beginning of the Chalcolithic at about 3000 BC until the end of the Early Bronze Age about 1650 BC in the Southeast (Schuhmacher 2012). Our preliminary work has revealed that the aggregate number of prehistoric ivory objects known, and thus the scale of ivory exchange, is much greater than previously thought. In fact, we have identified 160 ivory objects found in Portugal, without counting a larger amount of some 500 objects from the settlement of Perdigões (Alentejo), currently under study.

As a result, the ivory objects from Leceia were published again after their examination by A. Banerjee and Th. Schuhmacher (Schuhmacher and Cardoso 2007; Schuhmacher et al. 2009; Cardoso and Schuhmacher 2012). At the same time, the results of the first ever scientific analysis undertaken on Portuguese ivory were presented, focusing on the problems of ivory from African savannah elephant and from Elephas antiquus. This included pieces from Leceia as well as others from Anta da Herdade da Capela (Avis, Portalegre, Alentejo), Nora (Cacela, Vila Real de Santo António, Faro,

Trab. Prehist., 70, N. ${ }^{\circ}$ 1, enero-junio 2013, pp 185-203, ISSN: 0082-5638

doi: $10.3989 /$ tp.2013.12109 


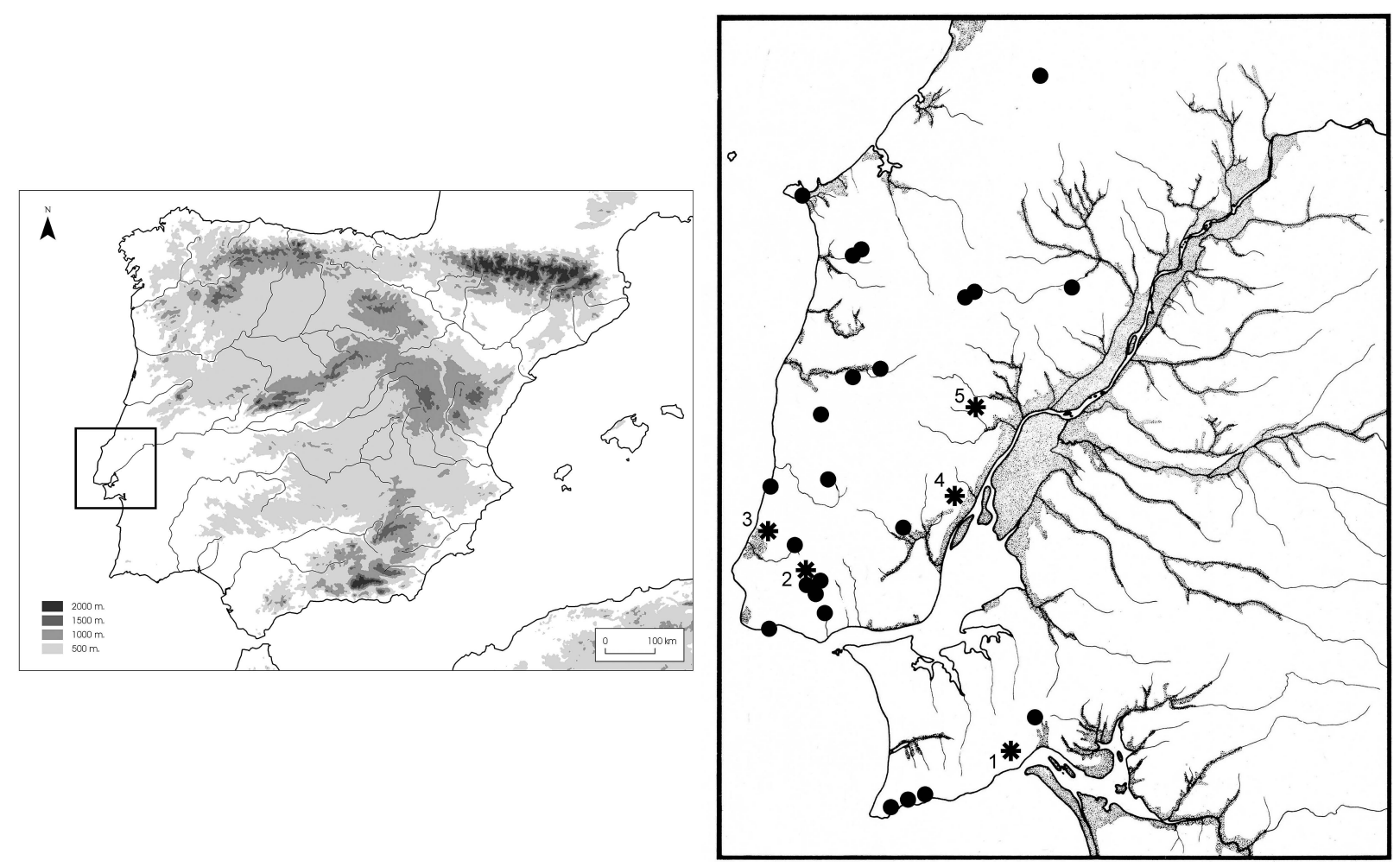

Fig. 1. Atlantic Central Portugal. Distribution of the ivory objects in the Chalcolithic. Sperm whale ivory: 1 Rock cut necropolis of Palmela; 2 Dolmen das Conchadas; 3 burial monument of Praia das Maçãs (in Fig. 3); 4 burial cave of Verdelha dos Ruivos; 5 settlement of Pedra do Ouro.

Algarve), Palmela (Quinta do Anjo, Setúbal, Estremadura) and Verdelha dos Ruivos (Vialonga, Vila Franca de Xira, Lisbon, Estremadura), all deposited in the Museu Nacional de Arqueologia in Lisbon.

\section{OBJECTS UNDER ANALYSIS}

Among these ten objects hence analysed, four were made of ivory from the African Savannah Elephant (Loxodonta africana africana) and one from Elephas antiquus (Schuhmacher et al. 2009; Banerjee et al. 2011a; Cardoso and Schuhmacher 2012). But at the same time, the five buttons from Verdelha dos Ruivos gave a totally different result.

In 1973 rescue excavations in the burial cave of Verdelha dos Ruivos delivered 44 internments, most of them belonging to a Bell Beaker context, as also demonstrated by four ${ }^{14} \mathrm{C}$-dates, which range from 2858-2346 cal $\mathrm{BC}$ (1) (Leitão et al. 1984; Cardoso and Soares 1990-92; Cardoso 2001). From a total of six ivory buttons, all clearly representing the Bell Beaker period (aprox. 25002000 BC) and unearthed in these burials, we sent five buttons for scientific analysis (Fig. 2: 1-5). In each example, the buttons have a perpendicular middle and two big trapezoidal appendages (2) (Leitão et al. 1984: figs. 2, 6.8.9.19; 3, 24; Salvado 2004: pl. 10, 6.7.8.9.10; Schuhmacher, in press: cat. No. 139. 140. 142-144). A V-formed perforation is placed in longitudinal direction. The length of each ranges from 2,2 to $2,4 \mathrm{~cm}$, the

(1) ${ }^{14} \mathrm{C}$ - dates GrN-10971 (bone): $3960 \pm 40 \mathrm{BP}$; GrN-10972 (bone): $4100 \pm 60 \mathrm{BP}$; GrN-10973 (bone): $4100 \pm 60 \mathrm{BP}$; ICEN1242 (human bone): $3940 \pm 45$ BP. For the calibration of all the radiocarbon dates we used $\mathrm{OxCal} 4.1$ with a standard deviation of $1 \sigma$ (Bronk Ramsey 2009).

(2) Museu Nacional de Arqueologia, Lisbon: Inv. Nos. 989.13.1; 989.13.2.; 989.13.3; 989.13.4; 989.13.5. 
width from 1,3 to $1,6 \mathrm{~cm}$ and their height from only 0,4 to $0,6 \mathrm{~cm}$.

The results were totally unexpected: The analysis determined that these buttons were made of sperm whale ivory. Prior to these results, the common opinion was that marine ivory had not been used before the Middle Ages (compare Pastor 1994). These objects had been selected for analysis with the goal of obtaining information about the type of ivory used during the Bell Beaker period, specifically in the production of such V-perforated buttons. Therefore, because of the unexpected result, we decided to select more pieces of Bell
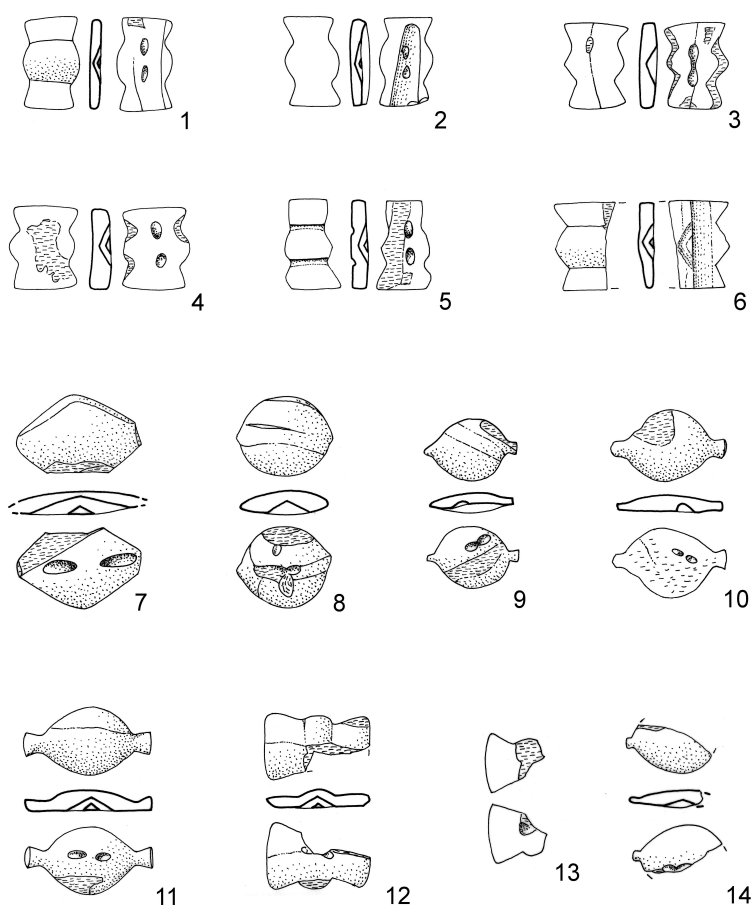

14

0
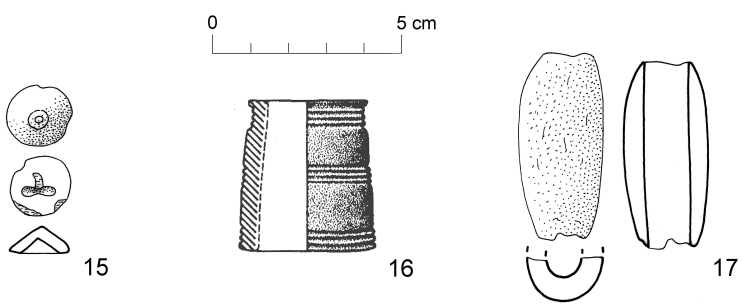

Fig. 2. Chalcolithic objects under analysis: 1-15 buttons, 16 decorated cilinder, 17 cylindrical bead. 1-5 burial cave of Verdelha dos Ruivos; 6-15 Palmela rock cut tomb 1; 7-11 settlement of Pedra do Ouro; 12-14 Dolmen das Conchadas; 16-17 burial monument of Praia das Maçãs (in Fig. 3).
Beaker chronology to confirm these results or to find out what type of ivory was normally used in Portugal in those times. For this purpose several objects from four different sites, Praia das Maçãs (Sintra, Lisbon, Estremadura), Palmela, Dolmen das Conchadas (Belas, Sintra, Lisbon, Estremadura) and Pedra do Ouro (Alenquer, Lisbon, Estremadura), all situated near the Tejo estuary and belonging to the collections of the Museu Geológico and the Museu Arqueológico do Carmo (both Lisbon) have been studied by scientific analysis (Schuhmacher and Banerjee 2011).

The burial monument of Praia das Maçãs, discovered in 1927, is a quite complex construction (Leisner 1965: 44-68; Leisner et al. 1969; Kalb 1981: 59 f; Gonçalves 1982-83; Cardoso and Soares 1995) (Fig. 3). The oval main chamber is $5.5 \mathrm{~m}$ to $4.4 \mathrm{~m}$ big and excavated in the rock. The rock face is covered by masonry of small stones. It is probable that a false dome once existed. At the western side of this tholos a small gate leads to a transverse room, 4, $9 \mathrm{~m}$ to $0,9 \mathrm{~m}$ big. Its western side opens to a $1.5 \mathrm{~m}$ long corridor which leads to the Western chamber, a room with a dimension of $2 \mathrm{~m}$ to $2.5 \mathrm{~m}$, completely excavated in the rock. It was probably vaulted, but the ceiling had collapsed in antiquity. The whole burial complex has been covered by a barrow.

The first systematic excavation was undertaken by V. Leisner, G. Zbyszewski and O. da Veiga Ferreira in the year 1961. In 1979, in two campaigns, the whole monument was cleaned and parts of the atrium and the barrow excavated. We can distinguish two construction phases, the Western Chamber, and the later attached tholos. Also, the offerings of these two areas are different. First, we find engraved schist plaques and decorated needle heads only in the Western Chamber, while on the contrary cylindrical and idols with narrowed neck, boxes and stone vessels are only present in the tholos. Inside the tholos but near the entrance and in the corridor leading from the outside to the tholos we already find Bell Beaker elements. These differences clearly do have chronological and not social reasons, so we can differentiate three horizons, Western Chamber, tholos and Bell Beaker burials. The Western Chamber should mainly belong to the beginning of the Chalcolithic and the tholos to a younger phase of the Early Chalcolithic, being followed by Bell Beaker secondary burials. This is highlighted by three ra-

Trab. Prehist., 70, N. ${ }^{\circ}$ 1, enero-junio 2013, pp 185-203, ISSN: 0082-5638 doi: $10.3989 /$ tp.2013.12109 

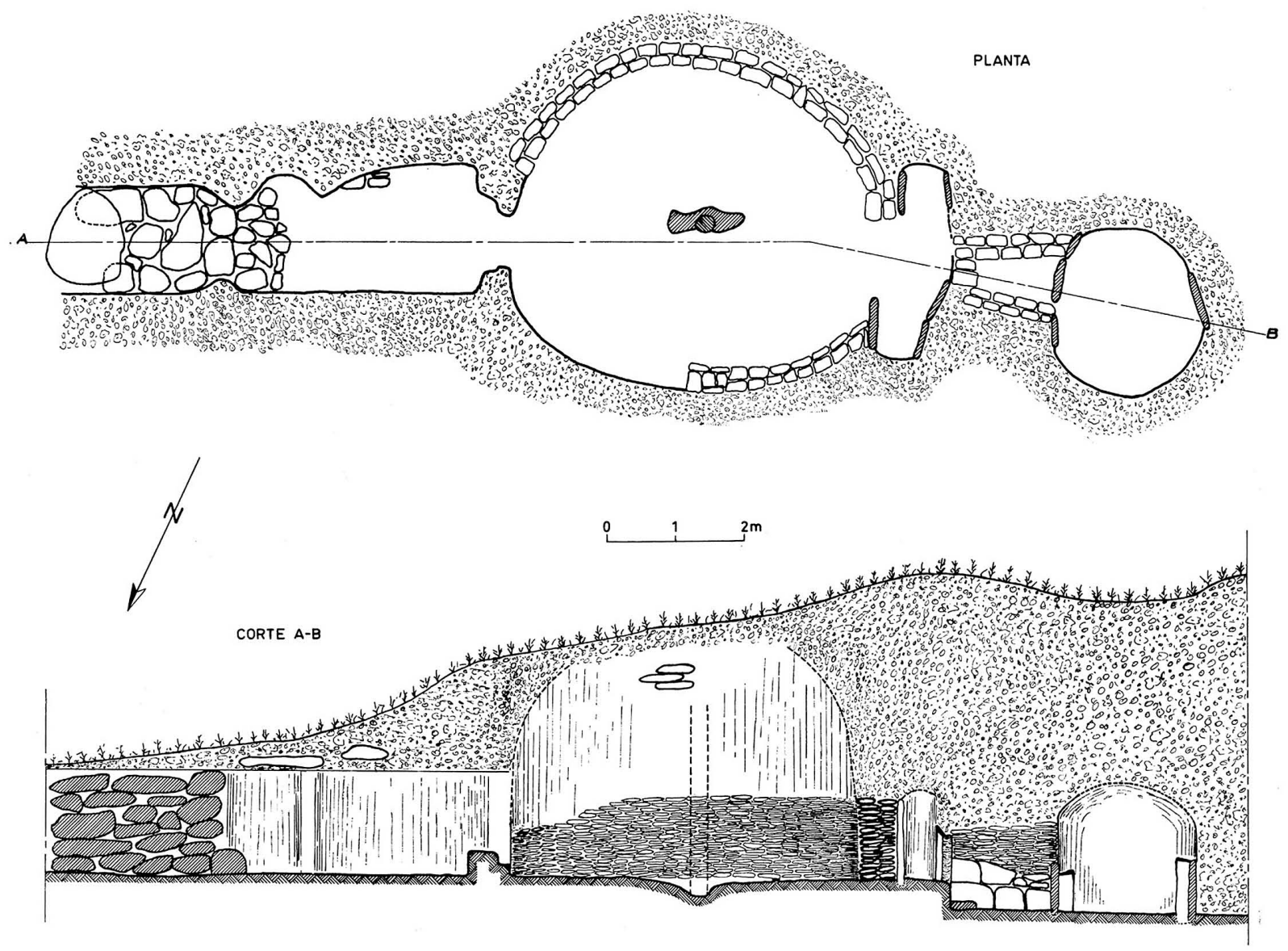

Fig. 3. Praia das Maçãs. Plan and cross section of the burial monument (after Leisner et al. 1969, pl. A).

diocarbon dates from the Western Chamber which span from 3312-2701 cal BC (3). One date from the tholos with 2133-1942 cal BC (4) probably gives a terminus ante quem for the construction of the tholos, although this date is not without problems (Leisner et al. 1969: 80f. 97 f; Castro et al. 1996: No. 1523).

We selected two out of several ivory objects for analysis (Leisner 1965: 56 pl. 41, 48; 42,85; Leisner et al. 1969: 37 pl. F 48. G 85; Spindler 1981: fig. 38, 11; Schuhmacher 2012: Cat. No. 112. 115). This example is a $3.8 \mathrm{~cm}$ high decorated cylinder from the unsystematic collection

(3) ${ }^{14} \mathrm{C}$-dates H-2049/1467 (carbon): $4260 \pm 60 \mathrm{BP}$; OxA5509 (ivory): $4410 \pm 75 \mathrm{BP}$ and OxA-5510 (ivory): $4395 \pm$ $60 \mathrm{BP}$.

(4) ${ }^{14} \mathrm{C}$-date H-2048/1458 (carbon): $3650 \pm 60 \mathrm{BP}$ (tholos). in the year 1927 (5) (Figs. 2: 16-17; 4). The narrower ending of this conical cylinder is contoured by four grooves. We find two more sets of four parallel grooves in the middle and on the wider ending. The second object is a cylindrical bead with a perforation in longitudinal direction, found inside the tholos (6). Only half of this object with a length of $4.9 \mathrm{~cm}$ and an outer diameter of 2.2 $\mathrm{cm}$ is preserved. Because of their parallels, we thought both objects likely belonged to a later phase of the Early Chalcolithic $\left(2^{\text {nd }}\right.$ quarter of the $3^{\text {rd }}$ millennia $\mathrm{BC}$ ), although a dating to the beginning of the $2^{\text {nd }}$ half of the $3^{\text {rd }}$ millennia $B C$ would also be possible.

The little necropolis of Palmela, formed by four vaulted rock-cut tombs, lies southeast of

(5) Museu Geológico Lisbon, Inv. Nr. PMC 82.

(6) Museu Geológico Lisbon, Inv. Nr. PMC 83.

Trab. Prehist., 70, N. ${ }^{\circ}$ 1, enero-junio 2013, pp 185-203, ISSN: 0082-5638 doi: $10.3989 /$ tp.2013.12109 
the village Quinta do Anjo (Costa 1907; Leisner 1965: 119-136, pl. 94-120; Soares 2003) (7). The tombs have been excavated in three different campaigns, around 1860-70, 1876-1878 and in the year 1906. All four tombs are identical and do have a circular chamber with a diameter of 4.6 to $5.5 \mathrm{~m}$ cut in the rock. The dome shows a little aperture. In front of the chamber lay an oval antechamber and a following narrow corridor.

The cylindrical grooved vessels prove utilisation at the beginning of the Chalcolithic. This is corroborated by two radiocarbon dates obtained from a needle's head and from human bones, giving an dating to 2836-2472 cal BC. Although vessels with "acacia leaf" and "cruciferae" decoration are not represented in Palmela this does not necessarily mean that the earlier period of the Early Chalcoli-

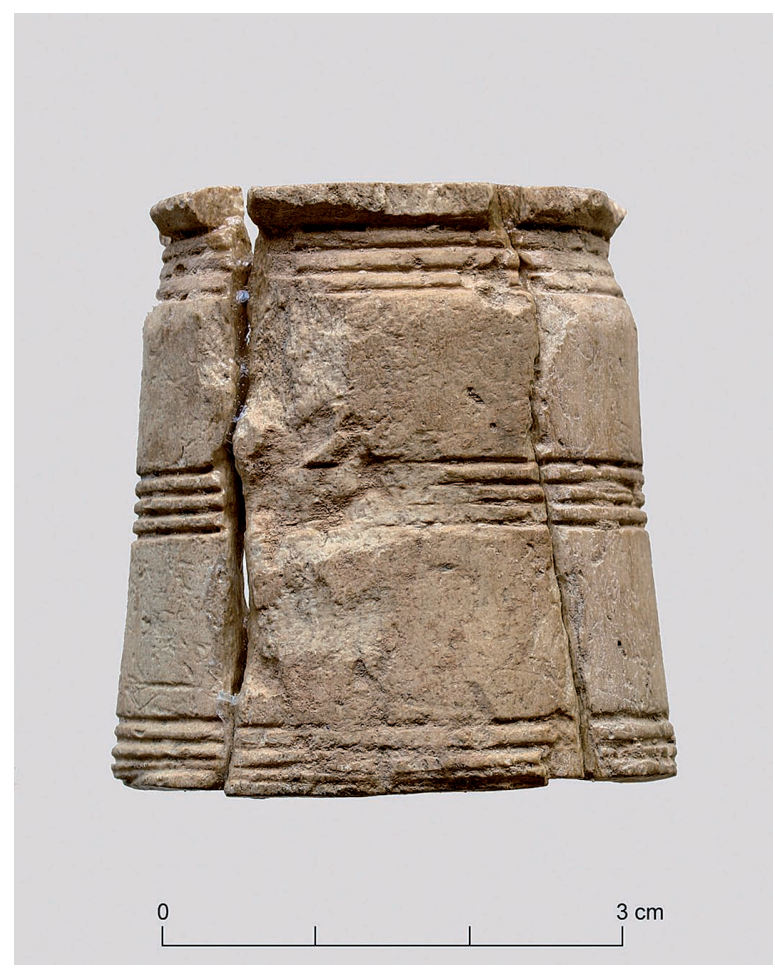

Fig. 4. Praia das Maçãs, burial monument. Decorated cylinder from the collection Caetano de Oliveira. Museu Geológico, Lisbon, Inv. No. PMC 82 (Negative No: DDAI-MAD-PAT-DG-008-2010-001; Photo: J. Patterson, DAI Madrid).

(7) ${ }^{14} \mathrm{C}$-dates OxA-5508 (bone): $4050 \pm 60 \mathrm{BP}$ and $\mathrm{GrN}$ 10744 (human bone): $4040 \pm 70$ BP. thic is completely missing. Among the Bell Beakers we observe vessels with international style decoration, supposedly dating to the beginning of the Bell Beaker phase. But most of the ceramics belong to the later Palmela and Inciso types.

Two buttons from tomb 1 were analysed (Leisner 1965: 122, No. 39. 43 pl. 95, 39.43; Uscatescu 1992: 161, Nos. 45. 314; Soares 2003: fig. 112a; Schuhmacher 2012: Cat. No. 91. 95) (Fig. 1: 6. 15). In one example, we find a button with oval middle part and two big trapezoidal appendages (8). A V-formed perforation is placed in the longitudinal direction. The button, of which half is missing, is $2,3 \mathrm{~cm}$ long and $0,5 \mathrm{~cm}$ high. The second button is conical with a circular base, a triangular cross-section and a V-formed perforation (9). The bridge of the perforation is fractured.

The Dolmen das Conchadas designates a corridor grave with polygonal chamber (Leisner 1965: $35-38$, pl. 28, 75. 77. 79). The chamber was already disturbed when C. Ribeiro investigated it in 1920, but he said the corridor seemed to have been intact. The offerings from the dolmen represent two phases of use. Thus, cylindrical idols, needles with cylindrical heads and channel decorated ceramics date to the Early Chalcolithic. Bell Beakers and V-perforated buttons document a secondary Bell Beaker occupation. We do not know the exact find-spots of the three buttons we choose for analysis, so they could come from the chamber as wells as the corridor.

Two of the three buttons selected have an oval middle part and two big trapezoidal appendices (Leisner 1965: 36f, pl. 27,41. 49. 53; Ferreira et al. 1961: 320f, pl. 4, 42; Schuhmacher 2012: cat. Nos. 31. 37. 39) (Fig. 1: 12-14) (10). There are remains of a $\mathrm{V}$-formed perforation, placed in longitudinal direction. The one complete button is $2.7 \mathrm{~cm}$ long and $1.2 \mathrm{~cm}$ wide. No buttons are higher than $0.5 \mathrm{~cm}$. The third button is a tortuga - button with two small pointed appendices (11). Half of the button is lacking. There are remains of a V-perforation placed in longitudinal direction.

The finds from Pedra do Ouro do not come out of a burial monument but rather a fortified settlement. This was already discovered in 1934 by H. Cabaço (Leisner and Schubart 1966; Do-

(8) Museu Geológico Lisbon, Inv. No. QAP 378.

(9) Museu Geológico Lisbon, Inv. No. QAP 379.

(10) Museu Geológico Lisboa, Inv. No. 302.51; 302.52.

(11) Museu Geológico Lisboa, Inv. No. 302.49.

Trab. Prehist., 70, N. ${ }^{\circ}$ 1, enero-junio 2013, pp 185-203, ISSN: 0082-5638

doi: $10.3989 /$ tp.2013.12109 

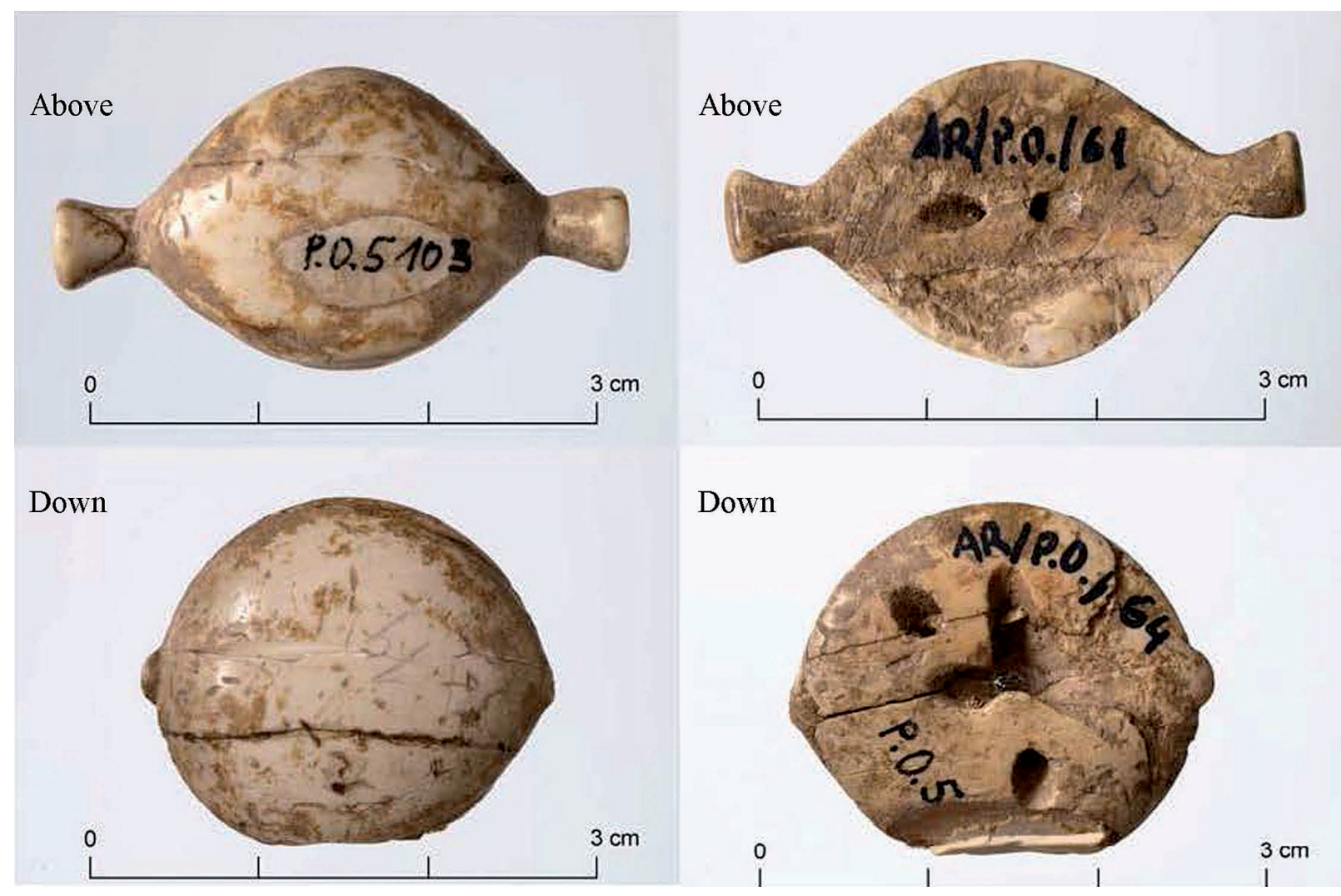

Fig. 5. Pedra do Ouro, fortified settlement. Tortuga - buttons with two small appendices. Museu Arqueológico do Carmo, Lisbon. Above: Inv. Nr. AR/PO/61 (Negative Nºs: D-DAI-MAD-PAT-DG-015-2010-007 and D-DAI-MAD-PATDG-015-2010-009. Down: Nr. AR/PO/64 (Negative Nºs: D-DAI-MAD-PAT-DG-015-2010-011 and D-DAI-MAD-PATDG-015-2010-012). Photos J. Patterson, DAI Madrid.

mingos and Gomes 1994; Gomes and Domingos 2005). He excavated the settlement partly, but thought it to be a barrow. In the following surveys a larger quantity of material was collected. V. Leisner and H. Schubart measured the fortification in 1965 and draw a plan. At the same time they published the finds of the collection Cabaço, stored in the museum of Alenquer. Finally V. dos Santos Gonçalves in 1973 and 1974 directed excavations on the site, but these have yet to be published.

According to the study of V. Leisner and $\mathrm{H}$. Schubart, the fortification follows the sides of the plateau, so that it has got pentagonal form. The wall that closes the only access to the plateau shows a pentagonal tower in each corner. Another fortification wall lays about $40 \mathrm{~m}$ in front of the inner fortification. The studied finds reveal the beginning of the settlement in the Early Chalco- lithic, although it reaches its climax in the Bell Beaker period. A new habitation follows in the Late Bronze Age and the Early Iron Age.

Three of the five buttons chosen for analysis are of tortuga - form with small trapezoidal appendages (Leisner and Schubart 1966; Domingos and Gomes 1994: figs. 198-202; Schuhmacher 2012: Cat. Nos. 103-107) (Figs. 2: 7-11; 5) (12). Their length ranges from $2,4 \mathrm{~cm}$ to $3,4 \mathrm{~cm}$, and their width between $1,6 \mathrm{~cm}$ and $1,8 \mathrm{~cm}$. Here too, the height is about $0,4 \mathrm{~cm}$ to $0,5 \mathrm{~cm}$. All do have a $\mathrm{V}$-formed perforation, placed in a somewhat eccentric position. In the case of another tortuga - button with two pointed appendices the perforation broke through twice, so that a new

(12) Museu Arqueológico do Carmo, Lisbon, Inv. Nr. AR/ $\mathrm{PO} / 60$ (= $\mathrm{PO} 5100) ; \mathrm{AR} / \mathrm{PO} / 61$ (= PO 5103); $\mathrm{AR} / \mathrm{PO} / 63$ (= PO 5104). 


\begin{tabular}{|c|c|c|c|c|}
\hline Site & Context & $\begin{array}{c}\text { Analysis Inv. } \\
\text { No. }\end{array}$ & $\begin{array}{l}\text { Museum } \\
\text { Inv. No. }\end{array}$ & Object \\
\hline Palmela & $\begin{array}{l}\text { Rock cut } \\
\text { tomb } 1\end{array}$ & Elf 201 & $\begin{array}{l}\text { MG: } \\
\text { QAP } 378\end{array}$ & button with big appendices \\
\hline Palmela & $\begin{array}{l}\text { Rock cut } \\
\text { tomb } 1\end{array}$ & Elf 206 & $\begin{array}{l}\text { MG: } \\
\text { QAP } 379\end{array}$ & conical button \\
\hline Verdelha dos Ruivos & $\begin{array}{l}\text { Burial cave, } \\
\text { Level II }\end{array}$ & Elf 739 & MNA: 989.13 .2 & button with big appendices \\
\hline Verdelha dos Ruivos & $\begin{array}{l}\text { Burial cave, } \\
\text { Level I }\end{array}$ & Elf 740 & MNA: 989.13 .1 & button with big appendices \\
\hline Verdelha dos Ruivos & $\begin{array}{l}\text { Burial cave, } \\
\text { Level I }\end{array}$ & Elf 741 & MNA: 989.13 .3 & button with big appendices \\
\hline Verdelha dos Ruivos & $\begin{array}{l}\text { Burial cave, } \\
\text { Level I }\end{array}$ & Elf 742 & MNA: 989.13 .5 & button with big appendices \\
\hline Verdelha dos Ruivos & $\begin{array}{l}\text { Burial cave, } \\
\text { Level I }\end{array}$ & Elf 743 & MNA: 989.13 .4 & button with big appendices \\
\hline Pedra do Ouro & Settlement & Elf 780 & $\begin{array}{l}\text { MAC: } \\
\text { PO 5101 = AR/PO/62 }\end{array}$ & rhombic button \\
\hline Pedra do Ouro & Settlement & Elf 781 & $\begin{array}{l}\text { MAC: } \\
\text { PO 5 .. = AR/PO/ } 64\end{array}$ & $\begin{array}{l}\text { tortuga button with small } \\
\text { appendices }\end{array}$ \\
\hline Pedra do Ouro & Settlement & Elf 782 & $\begin{array}{l}\text { MAC: } \\
\text { PO } 5104=\mathrm{AR} / \mathrm{PO} / 63\end{array}$ & $\begin{array}{l}\text { tortuga button with small } \\
\text { appendices }\end{array}$ \\
\hline Pedra do Ouro & Settlement & Elf 783 & $\begin{array}{l}\text { MAC: } \\
\mathrm{PO} 5100=\mathrm{AR} / \mathrm{PO} / 60\end{array}$ & $\begin{array}{l}\text { tortuga button with small } \\
\text { appendices }\end{array}$ \\
\hline Pedra do Ouro & Settlement & Elf 784 & $\begin{array}{l}\text { MAC: } \\
\text { PO } 5103=\mathrm{AR} / \mathrm{PO} / 61\end{array}$ & $\begin{array}{l}\text { tortuga button with small } \\
\text { appendices }\end{array}$ \\
\hline Dolmen das Conchadas & Corridor grave & Elf 909 & $\begin{array}{l}\text { MG: } \\
302.51\end{array}$ & button with big appendices \\
\hline Dolmen das Conchadas & Corridor grave & Elf 910 & $\begin{array}{l}\text { MG: } \\
302.49\end{array}$ & $\begin{array}{l}\text { tortuga button with small } \\
\text { appendices }\end{array}$ \\
\hline Dolmen das Conchadas & Corridor grave & Elf 913 & $\begin{array}{l}\text { MG: } \\
302.52\end{array}$ & button with big appendices \\
\hline Praia das Maçãs & $\begin{array}{l}\text { Collection Caetano de } \\
\text { Oliveira (1927) }\end{array}$ & Elf 939 & $\begin{array}{l}\text { MG: } \\
\text { PMC } 82\end{array}$ & decorated cylinder \\
\hline Praia das Maçãs & Tholos & Elf 940 & $\begin{array}{l}\text { MG: } \\
\text { PMC } 83\end{array}$ & cylindrical bead \\
\hline
\end{tabular}

Tab. 1. The analysed objects of Chalcolithic Portugal. MG = Museu Geológico; MNA = Museu Nacional de Arqueologia; MAC = Museu Arqueológico do Carmo. Lisbon.

perforation was placed diagonally (Fig. 5. down) (13). A quite rare form represents the rhombic button with V-perforation (14). It measures $3,2 \mathrm{~cm}$ in length, $2,1 \mathrm{~cm}$ in width and $0,6 \mathrm{~cm}$ in height (Tab. 1).

(13) Museu Arqueológico do Carmo, Lisbon, Inv. Nr. AR/ $\mathrm{PO} / 64$ (= PO 5---).

(14) Museu Arqueológico do Carmo, Lisbon, Inv. Nr. AR/ $\mathrm{PO} / 62$ (= PO 5101).

\section{ANALYSIS}

The primary aim of the scientific investigation was to identify the material out of which the chalcolithic artefacts are made. Bone-like archaeological finds may be made of animal bone or ivory. The term ivory is used not only for tusk of elephant, but also for teeth or tusk of other animals such as mammoths, walrus, hippopotamus and sperm whales. There are different analytical 
methods which are used for identifying the types and sources of ivory. Previously we had investigated many archaeological objects from Portugal, most of which were made of animal bone or elephant ivory. Therefore we were surprised when we found sperm whale artefacts among them.

\subsection{Methods applied for material identification}

The methods applied for material identification were 1) Optical microscopy, 2) Measurement of specific gravity, 3) Measurement of hardness, 4) Micro-Raman spectroscopy, 5) Elemental analysis, and 6) Isotopic Ratio Mass Spectrometry (IRMS).

1) Under the optical microscope different types of ivory can be distinguished from one another according to their internal morphology (Locke 2008). Basically all types of ivory, whether from teeth or tusk of animals, are composed of dentin and collagen. Dentine consists of micro-canals, called dentine tubules. Dentin tubules are embedded in the dentine mass. The arrangement of the dentine tubules in different types of ivory is different.

Different types of ivory can be distinguished from one another according to the typical structures on their surface, caused by the characteristic three dimensional arrangements of the dentine tubules (Espinoza and Mann 1991). The arrange- ment of the dentine tubules is under genetic control and is therefore a characteristic feature unique to the order.

In case of elephant tusk the dentine tubules (diameter ranging from 1 to 2 micron) radiate outward through the dentine mass from the pulp cavity to the exterior of the cementum border. The configuration of the dentine tubules forms in elephant ivory a structure, called "Schreger structure" named according to Bernhard Schreger, who observed this phenomenon for the first time (Schreger 1800). Under the optical microscope the Schreger structure can be observed on the crosssection of the elephant tusk as a cross-hatched pattern (Fig. 6, left) (Banerjee 2004). The Schreger structure is only present in Probiscidean dentine, that is why it can be observed only on ivory from elephant and mammoth. Sperm whale ivory on the other hand does not show the Schreger structure. Sperm whale ivory is confused with walrus ivory, because both have two distinct layers. Cross section of sperm whale ivory can be identified by the typical thick cementum with wide incremental growth layers and also by the numerous straight dentin canals with fine branches (Fig. 6, right).

2) The specific gravity of the objects under investigation was measured with the help of a hydrostatic balance. Ivory from sperm whale is characterised by its comparatively high specific gravity (Tab. 2 and 3).

3) The measurement of scratch-hardness of the samples was done by scratching them by hardness measuring pencils of known hardness according to

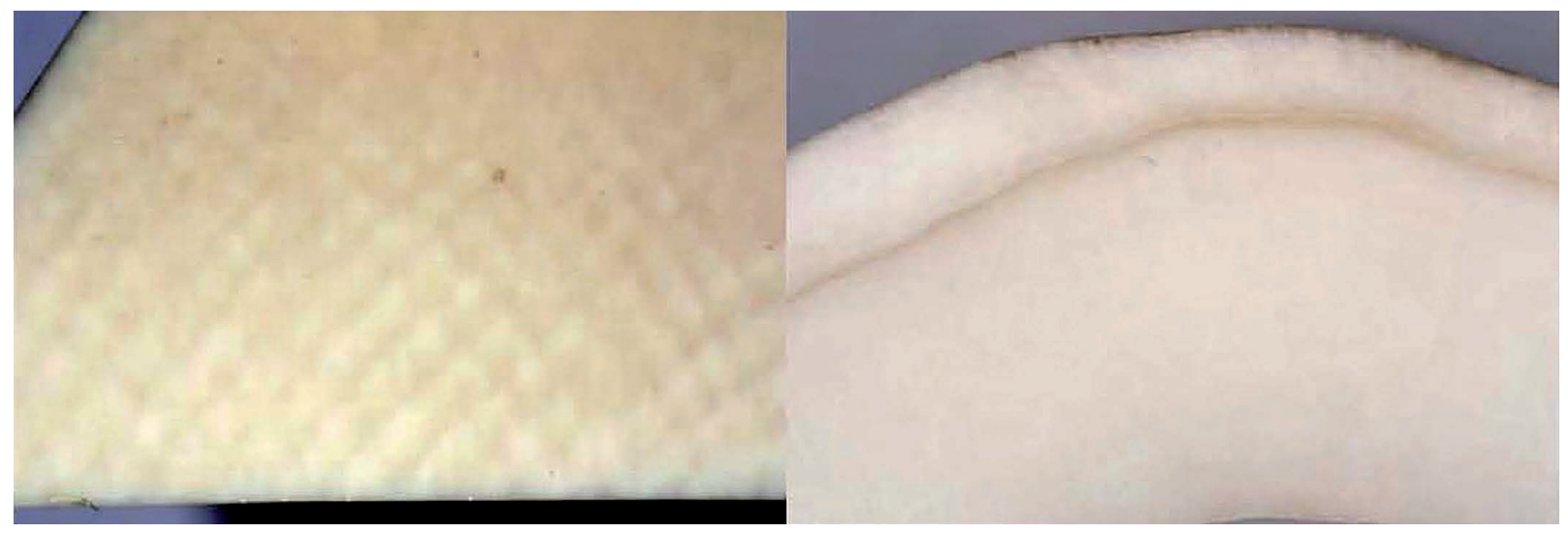

Fig. 6. Optical microscope. Elephant ivory (left) and sperm whale ivory (right). Photos V. Iserhardt, Römisch-Germanisches Zentralmuseum Mainz. 


\begin{tabular}{|l|c|}
\hline \multicolumn{1}{|c|}{ Type of ivory } & \multicolumn{1}{c|}{$\begin{array}{c}\text { Specific gravity } \\
\text { (average) }\end{array}$} \\
\hline Sperm whale & 2.2 \\
\hline Elephant ivory & 1.7 \\
\hline Mammoth ivory & 1.6 \\
\hline Hippopotamus ivory & 1.8 \\
\hline
\end{tabular}

Tab. 2. Specific gravity of the ivory objects of Chalcolithic Portugal under analysis.

\begin{tabular}{|l|c|}
\hline \multicolumn{1}{|c|}{ Sample } & Specific gravity \\
\hline Elf 201 & 2.35 \\
\hline Elf 206 & 2.29 \\
\hline Elf 739 & 2.41 \\
\hline Elf 740 & 2.31 \\
\hline Elf 741 & 2.20 \\
\hline Elf 742 & 2.25 \\
\hline Elf 743 & 2.29 \\
\hline Elf 780 & 2.27 \\
\hline Elf 781 & 2.21 \\
\hline Elf 782 & 2.26 \\
\hline Elf 783 & 2.21 \\
\hline Elf 784 & 2.24 \\
\hline Elf 909 & 2.26 \\
\hline Elf 910 & 2.28 \\
\hline Elf 913 & 2.27 \\
\hline Elf 939 & 2.29 \\
\hline Elf 940 & 2.34 \\
\hline
\end{tabular}

Tab. 3. Comparison of specific gravity of different types of ivory of Chalcolithic Portugal (see Tab. 1).

Moh's scale. It was proved that the average hardness of the samples under investigation was 3.5. In comparison, the hardness of elephant ivory is 2.5 .

4) Micro-Raman spectroscopy was named after its inventor Sir C. V. Raman. It is a non-destructive technique which does not need any sample preparation. As such it was an ideal method for the investigation of the chalcolithic objects. Its working principle involves illuminating a sample with monochromatic light using a spectrometer to examine light scattered by the sample. A laser is used as a source of incident photons that gain or lose energy when they interact with molecules in a sample, producing frequency shift in the scattered photons and is termed Raman shift. Micro-Raman spectroscopy enables us to investigate both inorganic and organic molecules.

Ivory is a composite material, which is composed of an inorganic and an organic component: The inorganic component is dentine, which is formed by crystallites of calcium-hydroxy-apatite. The organic component is collagen, a mixture of different types of proteins. Both dentine and collagen of ivory can be investigated simultaneously by Micro-Raman spectroscopy. Different types of ivory have different vibration modes and therefore different characteristic Raman spectra. Micro-Raman spectra of the objects under investigation in the frequency range between 500 and $1500 \mathrm{~cm}^{-1}$ were obtained using a confocal laser Raman system HR 800 (Jobin Yvon). The Raman spectrometer was equipped with a confocal microscope. Exciting radiation was provided by a Helium-Neon laser $(\lambda=632.817 \mathrm{~nm})$. The material of the samples under investigation was identified as sperm whale ivory by comparing their Micro-Raman spectra with those of standard sperm whale samples belonging to the collection of INCENTIVS of Mainz University. For example it was proved that samples Elf $780(\mathrm{AR} / \mathrm{PO} / 62)$, Elf 783 (AR/PO/61) and Elf $784(\mathrm{AR} / \mathrm{PO} / 61)$ are made of sperm whale ivory (Fig. 7). The Ramanshifts of sperm whale ivory were compared with those of elephant ivory.

5) Semi-quantitative analysis of sperm whale ivory was done for the elements carbon (C) and nitrogen $(\mathrm{N})$ using an automatic elemental analyser Vario EL apparatus (Elementar Analysen System, Hanau, Germany). The principle of the method comprises three steps: a) burning the sample at $1150^{\circ} \mathrm{C}$; b) catalytic processing of the generated gases $\left(\mathrm{CO}_{2}, \mathrm{H}_{2}\right.$ and $\left.\mathrm{N}_{2}\right)$ produced by burning and c) separation and detection of the different gases by thermo conductive detectors (TCD).

The amount of each gas was determined by TCD and a calibration curve. Percentage of each gas was calculated considering the amount of weighed sample.

This method has been successfully applied for the analysis of samples of elephant ivory (Baner- 

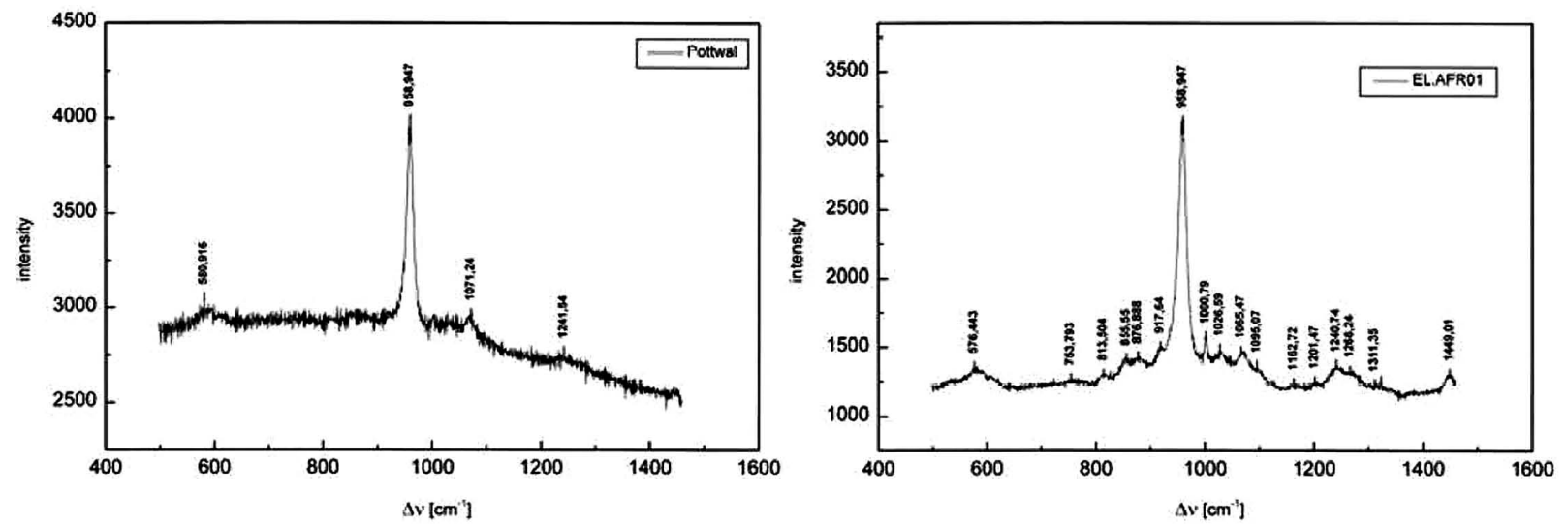

Fig. 7. Micro-Raman spectra of sperm whale ivory (left) and of African savannah elephant ivory (right).

\begin{tabular}{|l|l|l|}
\hline \multicolumn{1}{|c|}{ Sample } & $\mathbf{\% C}$ & $\mathbf{\% N}$ \\
\hline Elf $780(\mathrm{AR} / \mathrm{PO} / 62)$ & 6.62 & 0.82 \\
\hline Elf $783(\mathrm{AR} / \mathrm{PO} / 60)$ & 8.72 & 1.45 \\
\hline Elf $784(\mathrm{AR} / \mathrm{PO} / 61)$ & 7.71 & 1.77 \\
\hline Elf 201 & 9.21 & 0.65 \\
\hline Elf 206 & 8.55 & 1.85 \\
\hline Elf 739 & 7.85 & 0.92 \\
\hline Elf 740 & 8.20 & 1.55 \\
\hline Elf 741 & 6.50 & 1.48 \\
\hline Elf 742 & 6.41 & 0.82 \\
\hline Elf 743 & 7.22 & 1.90 \\
\hline Elf 781 & 6.20 & 0.85 \\
\hline Elf 782 & 7.80 & 1.90 \\
\hline Elf 909 & 7.65 & 0.88 \\
\hline Elf 910 & 8.30 & 0.89 \\
\hline Elf 913 & 7.65 & 1.95 \\
\hline Elf 939 & 6.46 & 0.95 \\
\hline Elf 940 & 9.60 & 0.98 \\
\hline
\end{tabular}

topes. This method has been used for the determination of the stable isotope ratios of carbon $\left({ }^{13} \mathrm{C} /{ }^{12} \mathrm{C}\right)$ and of nitrogen $\left({ }^{15} \mathrm{~N} /{ }^{14} \mathrm{~N}\right)$ of elephant ivory (Van der Merwe et al. 1990; Vogel et al. 1990). Accordingly IRMS was applied for the determination of the isotopic ratio of carbon ${ }^{13} \mathrm{C} /{ }^{12} \mathrm{C}$ for the samples under investigation. An amount of $2 \mathrm{mg}$ was taken from the samples for the measurement. It is pointed out that due to the relatively low concentration of nitrogen in the samples determination of nitrogen isotopic ratios $\left({ }^{15} \mathrm{~N} /{ }^{14} \mathrm{~N}\right)$ was not possible. The results of carbon isotopic ratios of three selected samples are given (Tab. 5). Whereas the measured carbon isotopic ratios $(\Delta \mathrm{C})$ of our samples lay around -25.00 , in the case of standards from African Savannah elephant ivory this value lays around -20.00 and in the case of Asian elephant ivory around -22.00 (Compare also Banerjee et al. 2011a).

Tab. 4. Results of Elemental analysis of the ivory objects of Chalcolithic Portugal under study. Carbon (C) and Nitrogen (N) (see Tab. 1).

jee et al. 2008). The results of the analysis of some of the samples of objects under investigation are given (Tab. 4).

6) Isotopic mass spectrometry (IRMS) is used for the measurement of mixtures of stable iso- 
1) Scanning electron microscopy (SEM): The internal structure of ivory can be observed under the microscope. SEM is more effective than the optical microscope for this purpose (Banerjee et al. 2011b). Dentine is composed of crystallites of calcium hydroxy phosphate. The size of these crystallites, which form the fundamental units of ivory, is different in different kinds of ivory. Moreover, as stated above, dentine contains also dentine tubules. The dimension and arrangement of the dentine tubules are different in different types of ivory. These main features, the sizes of the crystallites of calcium hydroxy apatite and the arrangement of the dentine tubules are revealed under SEM. As shown, sperm whale ivory can be distinguished from elephant ivory according to their SEM images (Fig. 8).

2) Particle Induced Gamma-ray Emission (PIGE): [Determination of Fluorine] As fluorine is present in soil and in water, it plays a significant role in archaeology. As such fluorine can be detected as trace element in archaeological objects made of ivory, because they absorb

\begin{tabular}{|l|c|}
\hline \multicolumn{1}{|c|}{ Sample } & $\Delta \mathbf{C}$ per mil \\
\hline Elf $780(\mathrm{AR} / \mathrm{PO} / 62)$ & -24.27 \\
\hline Elf $783(\mathrm{AR} / \mathrm{PO} / 60)$ & -25.56 \\
\hline Elf $784(\mathrm{AR} / \mathrm{PO} / 61)$ & -24.58 \\
\hline Elf 201 & -23.45 \\
\hline Elf 206 & -25.50 \\
\hline Elf 739 & -24.81 \\
\hline Elf 740 & -25.10 \\
\hline Elf 741 & -26.05 \\
\hline Elf 742 & -24.37 \\
\hline Elf 743 & -25.02 \\
\hline Elf 781 & -24.15 \\
\hline Elf 782 & -23.91 \\
\hline Elf 909 & -24.12 \\
\hline Elf 910 & -24.25 \\
\hline Elf 913 & -23.65 \\
\hline Elf 939 & -24.30 \\
\hline Elf 940 & -23.89 \\
\hline
\end{tabular}

Tab. 5. Values of Carbon isotopic ratios ( $\Delta \mathrm{C})$ of some selected samples of the ivory objects of Chalcolithic Portugal (cf. Tab. 1). fluorine from their burial environment. PIGE is a very sensitive nuclear technique used for the light element analysis in material science (Coote 1992; Sastri and Blondiaux 1997; Sastri et al. 2001). As the method is rapid, non-destructive and requires no special sample preparation, it has found application also in art and archaeology (Demortier and Bodart 1982; Reiche et al. 2000).

PIGE is a very popular method for fluorine and was applied for analysing fluorine in some samples of sperm whale ivory (recent) and in some samples of elephant ivory (recent). Our intention was to compare the accumulation of fluorine in two types of ivory, originating from two different environments.

PIGE is based on coulomb excitation of the nucleus and the generated $\gamma$ - spectra are simple to interpret. While recording $\mathrm{F}$ spectra, the irradiations yielded results on $\mathrm{Na}$ and $\mathrm{Mg}$, simultaneously. Hence all the three elements were determined. The nuclear reactions useful for the determination of $\mathrm{F}, \mathrm{Na}$ and $\mathrm{Mg}$ and the characteristic $\gamma$-rays measured are indicated below. The selected $\gamma$-rays are such that they are free from interference from other elements.

$$
\begin{array}{ll}
{ }^{19} \mathrm{~F}\left(\mathrm{p}, \mathrm{p}^{\prime} \gamma\right){ }^{19} \mathrm{~F} & (110 \mathrm{keV}, 197 \mathrm{keV}) \\
{ }^{23} \mathrm{Na}\left(\mathrm{p}, \mathrm{p}^{\prime} \gamma\right)^{23} \mathrm{Na} & (440 \mathrm{keV}) \\
{ }^{24} \mathrm{Mg}\left(\mathrm{p}, \mathrm{p}^{\prime} \gamma\right){ }^{24} \mathrm{Mg} & (585 \mathrm{keV})
\end{array}
$$

The irradiations were performed with the Van de Graaff accelerator at CNRS-CEMHTI, Orléans, France. The PIGE set-up was attached to the end of the beam line, and the samples were mounted at $45^{\circ}$ to the bombarding beam. The irradiations were performed with $2.3 \mathrm{MeV}$ proton beam. The sperm whale and elephant specimens were irradiated at 20-30 nA for 15 to $30 \mathrm{~min}$. Each sample was analysed at least twice. As standards $\mathrm{CaF}_{2}$ for $\mathrm{F}, \mathrm{NaF}$ for $\mathrm{F}$ and $\mathrm{Na}$, and $\mathrm{Mg}$ metal for $\mathrm{Mg}$ were used. The standards were irradiated at 1 to $2 \mathrm{nA}$ for ca. $5 \mathrm{~min}$. The beam size incident on the sample was $2 \mathrm{~mm} \times 2 \mathrm{~mm}$ (approx.). Counting was performed with a Ge (Li) detector of $10 \%$ efficiency which was located directly below the target and at $90^{\circ}$ to the incident beam. The stopping powers required to account for the range differences between standards and ivory matrix were taken from the tables of Ziegler et al. (2008). The results on $\mathrm{F}, \mathrm{Na}$ and $\mathrm{Mg}$ in three sperm whale (recent) samples are presented below (Fig. 9, down). For the sake of comparison, the 


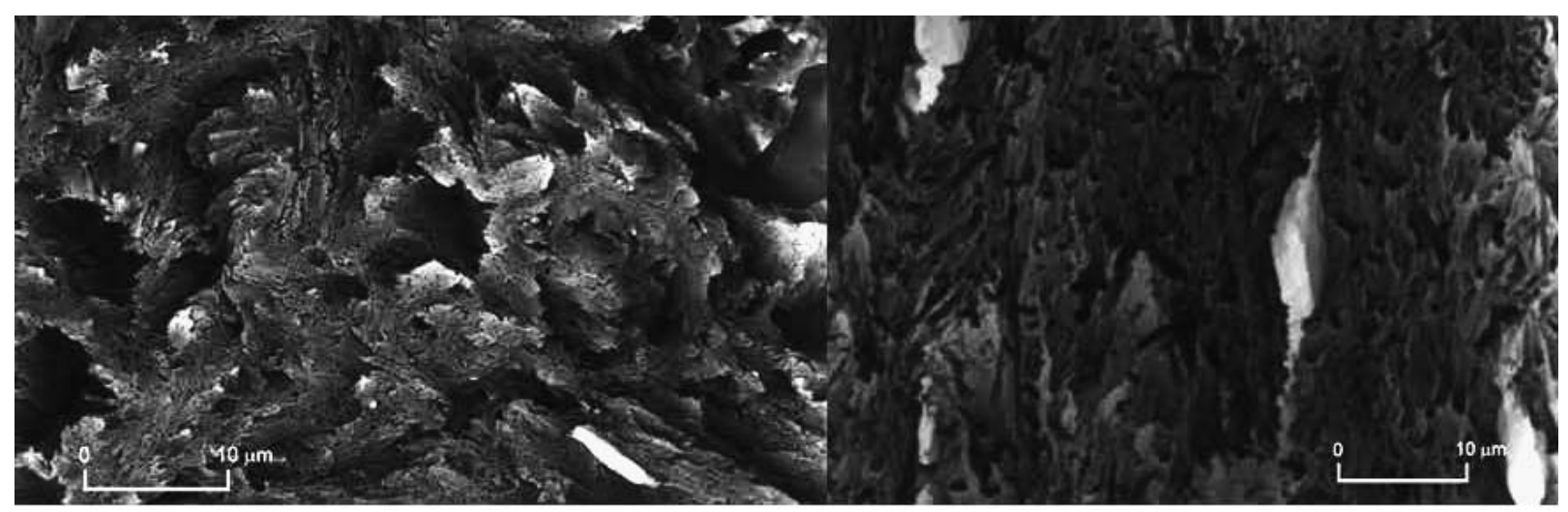

Fig. 8. Scanning Electron Microscopy images of sperm whale (left) and elephant ivory (right).

results of an African savannah elephant (recent) are also included.

The PIGE spectra of sperm whale and savannah elephant (Nigeria) ivory are shown here (Fig. 9). One notice that $\mathrm{F}$ and $\mathrm{Na}$ values are much higher in sperm whale than in elephant ivory, where the increase is most probably due to the living conditions, namely the aquatic environment of sperm whales. Raubenheimer (1999) and Sastri et al. (2013) have found similar low F values in African elephants.

\section{CONCLUSION}

Archaeologists frequently find artefacts made of bonelike materials during excavation. It is important to analyse them by modern analytical methods in order to identify the type and source of the material. Archaeological artefacts made of sperm whale ivory are very scarce. Until now no detailed analysis on chalcolithic archaeological sperm whale ivory from Portugal has been published. We have for the first time analysed authentic samples of this kind. Therefore the analytical results obtained by our investigation will be helpful to identify this material in future.

As shown, all 17 objects are made out of ivory from the sperm whale (Physeter macrocephalus) (Tab. 1). This was an unexpected result, as until now there was no hint about a use of marine ivory in Chalcolithic Iberian Peninsula. Only two of the objects, a decorated cylinder and a cylin- drical bead from Praia das Maçãs could belong to a younger moment of the Early Chalcolithic, although we cannot exclude a later dating. The whole rest belongs clearly to the Bell Beaker period (ca. 2500-2000 $\mathrm{BC}$ ).

The sperm whale (spanish and portuguese: cachalote; french: cachalot; italian: capodoglio; german: Pottwal) is with a maximum length of $18 \mathrm{~m}$ and a weight of 57 tons the biggest species among the toothed whales (Fernández-Casado 2000). The females are a little bit smaller and reach about $12 \mathrm{~m}$ and a weight of 24 tons. It is easily identifiable because of its big quadrangular head. Only the lower jaw shows between 17 and 29 pairs of conical teeth. These can reach a length up to $25 \mathrm{~cm}$ and a weight of $500 \mathrm{~g}$.

The sperm whale is present in all global deep waters, including the Mediterranean. They migrate in winter to tropical waters and in summer to the cooler polar waters. Whereas the males in summer can migrate to the polar margins, the females do not go further than $40^{\circ}$ or $50^{\circ}$ latitude. They feed on several species, notably the giant squid, colossal squid, octopuses and diverse fish like demersal rays. However, their main diet consists of medium-sized squid. They only come closer to the coast in those areas where the continental shelf drops quickly to depths of several hundred of meters, for example along coasts of Hawaii and the Azores, but they also are found in straits which separate two deep water basins like the ones of Gibraltar and Messina in the Mediterranean.

The oldest proofs for active whaling are, supposedly, the engravings from Bangu-dae (Ulsan) 

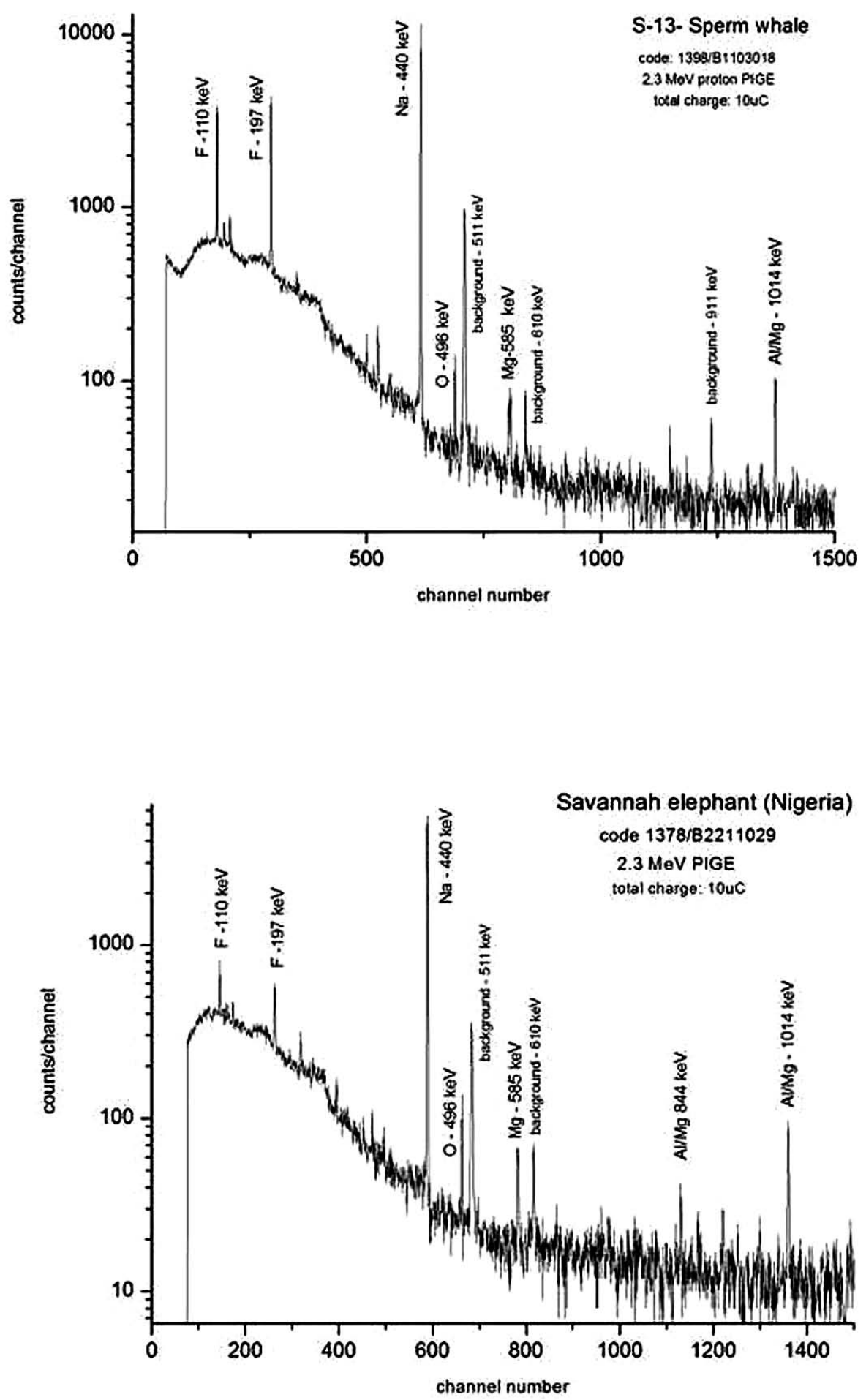

Fig. 9. Particle Induced Gamma-ray Emission spectra. Above: sperm whale ivory (Sample S 13). Down: savannah elephant (Nigeria) ivory. Channel number: Concentrations of F, $\mathrm{Na}$ and $\mathrm{Mg}$ in sperm whale and savannah elephant ivory according to Particle Induced Gamma-ray Emission. One notices that the values of F (1290 $\mu \mathrm{g} / \mathrm{g}$, Sample S13) and Na $(9135 \mu \mathrm{g} / \mathrm{g})$ (counts/channel) in this spectrum of a sperm whale ivory are much higher than the values of $\mathrm{F}(75 \mu \mathrm{g} / \mathrm{g})$ and $\mathrm{Na}(3570 \mu \mathrm{g} / \mathrm{g})$ in the spectrum of elephant ivory.

Trab. Prehist., 70, N. ${ }^{\circ}$ 1, enero-junio 2013, pp 185-203, ISSN: 0082-5638

doi: $10.3989 /$ tp.2013.12109 
in today South Korea (Lee and Robineau 2004). Here several dozens of cetaceans, most probably North Pacific right whale (Eubalaena japonica), humpback whale (Megaptera novaeangliae), gray whale (Eschrichtius robustus) and also sperm whale (Physeter macrocephalus), are depicted together with humans in boats. We can identify harpooning and others scenes where big nets are employed. This together with the appearance of whale bones in nearby Neolithic settlements, dating between 5000 and $1500 \mathrm{BC}$, suggest that whales were already hunted. Although some authors still interpret these finds of bones to be the result of scavenging of stranded animals (Fielding 2010: 21), we believe hunting to be quite clear, with the only problem being the dating of the scenes of Bangu-dae. Several styles of graving can be differentiated. Already among the oldest style A we observe a whale connected to a boat by a line (harpoon?). But most of the pictures of cetaceans belong to the following style B. Surely several generations of Neolithic fishermen and hunters created these scenes. Harpoons in fact are known from the nearby Neolithic site of Dongsam-Dong. Here in all archaeological levels, dating from 3500 to $1800 \mathrm{BC}$, numerous whale bones have been found too.

At Amaknak Bridge on Unalaska Island (Eastern Aleutians) a greater quantity of whale bones, long-finned pilot whale (Globicephala melas), beluga (Delphinapterus leucas), fin whale (Balaenoptera physalus), humpback whale, Baird's beaked whale (Berardius bairdii) and North Pacific right whale, together with toggling harpoons and lances seem to testify whaling later in time between 1950 and 420 cal BC (Crockford 2008).

And on the Russian Chukotka Peninsula in Un'en'en, near the modern whaling village of Nunligran, a Russian-American team discovered an object made of walrus ivory and engraved with scenes of men in umiaks (wooden framed boats covered in seal or walrus hide) harpooning whales (Catling 2008; Witze 2008) (15). This object was found sealed by the roof timbers of a collapsed structure that has been radiocarbon dated to 1000 BC. There are still some doubts about this dating, but at least from 2300/2000 BP onwards, whaling

(15) Excavations directed by S. V. Gusev (Russian Research Institute for Cultural and Natural Heritage, Moscow) and D. Odess (University of Alaska Museum of the North). seems to have arisen fully developed on Chukotka Peninsula (Savelle 2005; Crockford 2008: 113144, 123-124).

Later, the Thule Eskimo culture has been characterized as a whale hunting community (McCartney 1980). Recently there has been criticism of this view, especially on the question of whether the numerous findings of whale bones necessarily have to signify active whale hunting or could not also be the result of scavenging of stranded or dead whales or whale bone collecting. McCartney, after an extensive regard on the facts, comes to the conclusion that bowheads (Balaena mysticetus) were hunted and extensively used in Classical Thule (1000-1300 AD). But there haven been regional variants of Thule culture so that not all settlements depended in the same degree on whaling.

As regards Europe, there is some evidence of Anglo-Saxon and Norman whaling as early as the seventh or tenth centuries (Clark 1947; Fielding 2010: 23-24). For the year 1059 AD it was said that whaling was practiced in the town of Bayonne (France) and as early as $1150 \mathrm{AD}$ the hunting of the North Atlantic Right Whale spread to the Spanish Basque region. The Basque were the first to develop a whaling industry and to travel far from home to pursuit the whale, so that whaling was well established there commercially in the thirteenth century.

Focusing on Portugal, we observe that the coast of Central Portugal has three important submarine valleys, the ones of Nazaré, Lisbon and Setúbal, with deep waters very close to the coast, and which result in rich fishing grounds and a variety of 13 cetacean species (Brito 2007; Brito et al. 2009). In the $12^{\text {th }}$ century whale products were already used in several Portuguese fishing villages, but it is not before the $13^{\text {th }}$ and $14^{\text {th }}$ century that we can say with surety that active whaling was practised in several locations on the continental coast. Landbased whaling on mainly fin and sperm whale then went on with peaks and decreases until 1951.

So whales, and also sperm whales surely lived near the Portuguese coast in the Chalcolithic as they still do today. The fact that prehistoric man observed and knew these impressive animals easy to watch is highlighted by some engravings on megalithic tombs in Brittany (France), Spanish Galicia and in Northern Portugal (Cassen and Vaquero 2004). So pictures from sites near the entry to the Morbihan gulf (Mané Rutual, Kercado, Petit Mont,

Trab. Prehist., 70, N. ${ }^{\circ}$ 1, enero-junio 2013, pp 185-203, ISSN: 0082-5638 doi: $10.3989 /$ tp.2013.12109 
Gavrinis, Pen Hap and the Grand Menhir of Locmariaquer), nearby Tuchenn Pol and Dissignac, the Galician sites of Dombate, Casa dos Mouros and Espiñaredo 10 and the Portuguese ones of Paços da Ferreira and Châ de Parada 1 have recently been identified as such of sperm whales.

But nevertheless it seems not likely to bring our Portuguese objects made out of sperm whale ivory in relation with active whaling during the Chalcolithic. So we do not know any Chalcolithic or Bronze Age harpoons or objects that might have been used as such. Also more primitive forms of hunting as could be driving the whales by boats into the Tejo estuary until they beach ('drive-style whaling') seem not probable, because there are no depictions of whale hunting and only very few whale bones in sites of this period (Fielding 2010: 25-27). This includes a bone of a cetaceous used as an anvil in a pre-Beaker level of the Chalcolithic fortification of Leceia (Cardoso 1995a), bone fragments of a "big whale" in Zambujal (Driesch and Boessneck 1976: 96) and a so called idol in sandal form from Almizaraque (Almeria, Spain) made out of the cranial bone of a whale (Leisner 1965: 93 pl. 69, 5.6; Maicas 2007: 121f). But this seems all not enough to suppose active whaling.

On the contrary we believe that we are talking most likely about beached whales. Stranding of whales and among them also sperm whales happened and goes on. So a study of the number of sea mammals beached between 1996 and 1998 list only for continental Portugal 340 animals (Covelo and Martínez 2001). Most of these are dolphins and not identified toothed whales, but there are also six sperm whales.

In the same sense, the earliest archaeological evidence of whale bones in various Mesolithic European sites, in many of the earliest North Pacific and Bering Sea and in pre-colonial sites in other parts of the world are traditionally viewed as result of the scavenging of stranded whales (Clark 1947; Smith and Kinahan 1984; Savelle 2005). Thus, the use of beached whales was already of some importance for medieval maritime societies (Clark 1947; Barthelmess 2003) as an Anglo-Saxon inscription on a whale bone casket from about $700 \mathrm{AD}$ tells us. Additionally several medieval legal texts treat the claims of feudal landowners to whales beached on their shores.

Therefore, it is reasonable to posit the utilization of sperm whale ivory for the production of buttons in Chalcolithic Portugal talks about the exploitation of beached whales. It is possible that sperm-whale ivory, because of its greater hardness in comparison with elephant ivory, was especially suitable for buttons with V-perforations. Sperm whale ivory does have a hardness of 3.5 on the Mohs Scale in comparison to 2.5 of elephant ivory. These perforations do have a tendency to break through due to use. This is especially true for the types of buttons studied here, such as the so called tortuga - buttons, or the ones with lateral appendages because of their very small height.

On the other side we could observe, that the increase of ivory pieces and of the geographic expansion of their use observed in Bell Beaker times together with a growing exploitation of local resources as ivory of Elephas antiquus and, as it seems, sperm whale ivory, may be related to an increasing demand impossible to satisfy by more exotic raw material. But at the same time ivory from the African Savannah elephant was also used, as the analysis of pieces from Bell Beaker contexts in Perdigões (Alentejo, Portugal) and Camino de Yeseras (Madrid) demonstrates (Liesau et al. 2011; Schuhmacher and Banerjee 2012).

Outside of the practical advantage of this material in relation to bone for some purposes, we can only speculate about a magical meaning which the material of these huge sea animals might have had too. Thus we only refer to Barthelmess (2003) the more than 200 cases of whale bones hung in European churches, castles and town halls, often interpreted as bones of the biblical giant Goliath or of Leviathan. In the case of Chalcolithic Portugal, where this material most probably came from whales beached on the proper coast of Portugal, we think that prehistoric men knew the origin of this material. But, although they surely saw the living animals near the coast and were able to relate the beached examples to these animals, this might not exclude a possible magical meaning of these materials due to the big dimensions of sperm whales, their habitat in the sea and the even today in most cases still mysterious beaching of these creatures.

In our particular case, we also think that it illustrates part of the life of communities living close to the sea and in tight relationship to the sea (Fig. 2). A study on human teeth and bones from Chalcolithic burials in the cave of Lapa da Furada (Sesimbra, Portugal) revealed a high concentration of bromine $(\mathrm{Br})$ and strontium $(\mathrm{Sr})$,

Trab. Prehist., 70, N. ${ }^{\circ}$ 1, enero-junio 2013, pp 185-203, ISSN: 0082-5638

doi: $10.3989 /$ tp.2013.12109 
what speaks for a diet rich in sea-food (Carvalho et al. 2000). Cardoso (1995b) identified big globular stones with central groove from Leceia and other Chalcolithic sites in Portugal as net sinkers for fishing. We know that sea bream and gilthead formed part of the sea-food consumed in Leceia and Zambujal (Antunes and Cardoso 1995; Driesch and Boessneck 1976: 111). This confirms the exploitation of the sea shores by Chalcolithic people, although without requiring sophisticated means of fishing.

\section{ACKNOWLEDGEMENT}

L. Raposo, A. I. Santos and C. Martinho from the Museu Nacional de Arqueologia, M. Ramalho and A. Anacleto from the Museu Geológico and J. Morais Arnaud and C. Pereira from the Museu Arqueológico do Carmo (all Lisbon) for their friendly help and the permission to study and analyse these pieces. And the authors would also like to thank Mrs. B. Courtois, CNRS-CEMHTI, Orléans for technical assistance as well as Mrs. Ch. Panas, M. A., New York for correcting our English.

\section{BIBLIOGRAPHY}

Antunes, M. Telles and Cardoso, J. L. 1995: "Ictiofauna do povoado pré-histórico de Leceia (Oeiras)". Estudos Arqueológicos de Oeiras 5: 187-192.

Banerjee, A. 2004: "Vergleichende Untersuchungen der Schreger-Struktur von Stoßzähnen von Elefanten". Mainzer naturwiss. Archiv 42: 77-88.

Banerjee, A.; Bortolaso, G. and Dindorf, W. 2008: "Distinction between African and Asian Ivory". In G. Bortolaso (ed.): Elfenbein und Artenschutz. INCENTIVS-Tagungsbeiträge (2004-2007). Bundesamt für Naturschutz - Skripten 228: 37-49. Bonn.

Banerjee, A.; Dindorf, W.; Mikdad, A.; Reischmann, Th. and Schuhmacher, Th. X. 2011a: "Die Elfenbeinfunde aus Kehf-el-Baroud (Ziaïda, Ben Slimane, Marokko) und die Frage des Nordafrikanischen Elefanten". Madrider Mitteilungen 52: 113-138.

Banerjee, A.; Huth, J. and Dindorf, W. 2011 b: "Untersuchung von archäologischem Elfenbein". In A. Banerjee and Ch. Eckmann (eds.): Ivory and Archaeology. Proceedings of INCENTIVS-meetings 2004-2007. Römisch-Germanisches Zentralmuseum: RGZM-Tagungen 7. Mainz: 1-18.
Barthelmess, K. 2003: "Stranded whales in the culture and economy of medieval and early modern Europe. ISANA, July: 2.

Brito, C. 2007: "Assessment of catch statistics during land-based whaling in Portugal". Journal of the Marine Biological Association 2-Biodiversity Records 2007: 1-5.

Brito, C.; Vieira, N.; Sá, E. and Carvalho, I. 2009: "Cetaceans occurrence off the west central Portugal coast: a compilation of data from whaling, observations of opportunity and boat-based surveys". Journal of Marine Animals and Their Ecology 2 (1): 10-13.

Bronk Ramsey, C. 2009: "Bayesian analysis of radiocarbon dates". Radiocarbon 51 (1): 337-360.

Cardoso, J. L. 1995a: "Ossos de cetáceo utilizados no Calcolítico da Estremadura". Estudos Arqueológicos de Oeiras 5: 193-198.

Cardoso, J. L. 1995b: "Pesos de pesca do povoado préhistórico de Leceia (Oeiras). Estudo comparado". Estudos Arqueológicos de Oeiras 5: 107-119.

Cardoso, J. L. 2001: "Le phénomène campaniforme dans les basses vallées du Tage et du Sado". In F. Nicolis (ed.): Bell Beakers today. Pottery, people, culture, symbols in prehistoric Europe. Proceedings of the International Colloquium (Riva del Garda 1998): 139-154. Trento.

Cardoso, J. L. 2003: "O uso do marfim, no território português, durante o Calcolítico. A propósito de um alfinete recolhido no povoado pré-histórico de Leceia (Oeiras)". Estudos Arqueológicos de Oeiras 11: 85-96.

Cardoso, J. L. and Schuhmacher, Th. X. 2012: "Marfiles calcolíticos en Portugal: estado de la cuestión". In A. Banerjee, J. A. López Padilla and Th. X. Schuhmacher (eds.): Elfenbeinstudien. Faszikel 1: Marfil y Elefantes en la Península Ibérica y el Mediterráneo. Actas del Coloquio Internacional (Alicante 2008). Iberia Archaeologica 16 (1). Darmstadt/ Mainz: 95-110.

Cardoso, J. L. and Soares, A. M. 1990-92: "Cronologia absoluta para o Campaniforme da Estremadura e do Sudoeste de Portugal". O Arqueólogo Português S. IV, 8/10: 203-228.

Cardoso, J. L. and Soares, A. M. 1995: "Sobre a cronologia absoluta das grutas artificais da Estremadura portuguesa". Al-madan 4: 10-13.

Carvalho, M. L.; Casaca, C.; Pinheiro, T.; Marques, J. P.; Chevallier, P. and Cunha, A. S. 2000: "Analysis of human teeth and bones from the Chalcolithic period by X-ray spectrometry". Nuclear Instruments and Methods in Physics Research B 168: 559-565.

Cassen, S. and Vaquero, J. 2004: "Fabulous things". Journal of Iberian Archaeology 6: 7-48.

Castro Martínez, P. V.; Lull, V. and Micó, R. 1996: Cronología de la Prehistoria Reciente de la Península Ibérica y Baleares (c. 2800-900 calANE). British Archaeological Reports, International Series 652, Tempus Reparatum. Oxford.

Trab. Prehist., 70, N. ${ }^{\circ}$ 1, enero-junio 2013, pp 185-203, ISSN: 0082-5638 doi: $10.3989 /$ tp.2013.12109 
Catling, C. 2008: "Whaling in Arctic Prehistory". Current World Archaeology 29: 6.

Clark, G. 1947: "Whales as an economic factor in prehistoric Europe". Antiquity 21: 84-104.

Coote, G. E. 1992: "Ion beam analysis of fluorine: Its principles and applications". Nuclear Instruments and Methods in Physics Research Section B: Beams Interactions with Materials and Atoms 66, 1(2), March: 191-204.

Costa, A. I. Marques da 1907: "Estações pré-históricas dos arredores de Setúbal". O Arqueólogo Português 12: 206-217, 320-338.

Covelo, P. and Martínez, J. 2001: "Varamientos de mamíferos marinos en las costas de España y Portugal entre 1996 y 1998: Atlancetus”. Galemys 13: 93-106.

Crockford, S. J. 2008: "Be careful what you ask for: Archaeozoological evidence of mid-Holocene climate change in the Bering Sea and implications for the origin of Arctic Thule". In G. Clark, F. Leach and S. O'Connor (eds.): Islands of Inquiring: Colonisation, seafaring and the archaeology of maritime landscapes. Terra Australis 29, Australian National University. Canberra: 113-131.

Demortier, G. and Bodart, F. 1982: "Complementarity of PIXE and PIGE for the characterization of gold items of ancient jewelry". Journal of Radioanalytical and Nuclear Chemistry 69, 1(2): 239-257.

Domingos, J. and Gomes, J. J. 1994: "Objetos históricoarqueológicos de Alenquer no Museu da Associação dos Arqueólogos Portugueses". Actas das V Jornadas Arqueológicas da Associação dos Arqueólogos Portugueses 2: 229-237. Lisboa.

Driesch, A. von den and Boessneck, J. 1976: "Castro do Zambujal. Die Fauna”. Studien über Tierknochenfunde von der Iberischen Halbinsel 1, Institut für Palaeoanatomie, Domestikationsforschung und Geschichte der Tiermedizin der Universitat München. München: 43-95.

Espinoza, E. O. and Mann, M. J. 1991: Identification Guide for Ivory and Ivory Substitutes. World Wildlife Fund and Conservation Foundation. Baltimore, USA. Fernández-Casado, M. 2000: "El cachalote (Physeter macrocephalus)". Galemys 12-2: 3-22.

Ferreira, A. Ribeiro; Leisner, V. and da Veiga Ferreira, O. da Veiga 1961: "Monumentos megalíticos de Trigache ede A-da-Beja". Comunicações dos Serviços Geologicos de Portugal 45: 297-337.

Fielding, R. 2010: Artisanal whaling in the Atlantic: A comparative study of culture, conflict, and conservation in St. Vincent and the Faroe Islands. Dissertation Louisiana State University. http://etd.lsu.edu/ docs/available/etd-10152010-153405/unrestricted/ fielding_dissertation.pdf (consulted 8-II-2011).
Fernández Gomes, J. J. and Barreto Domingos, J. B. 2005: "Povoado fortificado da Pedra do Ouro". In J. Morais Arnaud and C. Varela Fernandes (eds.): Construindo a memória. As colecções do Museu Arqueológico do Carmo. Associação dos Arqueólogos Portugueses. Lisboa: 116-122.

Gonçalves, J. L. Marques 1982/83: "Monumento préhistórico da Praia das Maçãs (Sintra). Notícia preliminar". Sintria 1/ 2: 29-58.

Harrison, R. J. and Gilman, A. 1977: "Trade in the second and third millennia B.C. between the Maghreb and Iberia". In V. Markotic (ed.): Ancient Europe and the Mediterranean. Studies in honour of Hugh Hencken. Aris \& Phillips. Warminster: 90-104.

Kalb, P. 1981: "Zur relativen Chronologie portugiesischer Megalithgräber”. Madrider Mitteilungen 22: 55-77.

Lee, S. M. and Robineau, D. 2004: "Les cétacés des gravures rupestres néolithiques de Bangu-dae (Corée du Sud) et les débuts de la chasse à la baleine dans le Pacifique nord-ouest'. L'Anthropologie 108: 137-151.

Leisner, V. 1965: Die Megalithgräber der Iberischen Halbinsel. Der Westen. Madrider Forschungen I 3. Berlin.

Leisner, V. 1943: Die Megalithgräber der Iberischen Halbinsel. Der Süden. Römisch-Germanische Forschungen 17, W. de Gruyter. Berlin.

Leisner, V. and Schubart, H. 1966: "Die kupferzeitliche Befestigung von Pedra do Ouro/ Portugal“". Madrider Mitteilungen 7: 9-60.

Leisner, V.; Zbyszewski, G. and da Veiga Ferreira, O. 1969: Les monuments préhistoriques de Praia das Maçãs et de Casainhos. Memorias dos Serviços Geologicos de Portugal, N.S. 16. Lisboa.

Leitão, M.; North, C. T.; Norton, J.; da Veiga Ferreira, O. and Zbyszewski, G. 1984: "The Prehistoric Burial cave at Verdelha dos Ruivos (Vialonga), Portugal". In J. Guilaine (ed.): L'âge du cuivre européen. Civilisations à vases campaniformes. Éditions du Centre National de la Recherche Scientifique. Paris: 221-239.

Liesau, C.; Banerjee, A. and Schwarz, J. O. 2011: " 'Camino de las Yeseras' ivory collection: advances in analysis technology used in identifying raw material”. In C. Blasco, C. Liesau and P. Ríos (eds.): Yacimientos calcolíticos con campaniforme de la región de Madrid: nuevos estudios. Patrimonio Arqueológico de Madrid 6, Universidad Autónoma de Madrid. Madrid: 381-386.

Locke, M. 2008: "Structure of ivory". Morphology 269 (4): 423-450.

Maicas Ramos, R. 2007: Industria ósea y funcionalidad. Neolítico y Calcolítico en la cuenca de Vera (Almería). Bibliotheca Praehistorica Hispana, CSIC. Madrid.

McCartney, A. P. 1980: "The Nature of Thule Eskimo Whale Use". Arctic 33 (3): 517-541.

Pastor Vélez, B. 1994: "El trabajo del marfil durante el Bronce Final y la Edad del Hierro en la mitad 
norte peninsular". In $1^{\circ}$ Congresso de Arqueologia Peninsular, Actas III (Porto 1993). Trabalhos de Antropologia e Etnologia 34, 1-2: 191-213.

Poyato Holgado, C. and Hernando Grande, A. 1988: "Relaciones entre la Península Ibérica y el Norte de Africa: marfil y campaniforme". In Actas del Congreso Internacional 'El Estrecho de Gibraltar' (Ceuta 1987) I: 317-329. Madrid.

Raubenheimer, E. J. 1999: "Morphological aspects and composition of African elephant (Loxodonta africana) ivory". KOEDOE 42: 57-64.

Reiche, I.; Vignaud, C.; Calligaro, T.; Salomon, J. and Menu, M. 2000: "Comparative analysis of odontolite, heated fossil ivory and blue fluorapatite by PIXE/PIGE and TEM". Nuclear Instruments and Methods in Physics Research Section B: Beams Interactions with Materials and Atoms 161: 737-742.

Salvado, M. C. and Ruivo da Silva, B. 2004: Apontaments sobre a utilização do osso no Neolítico e Calcolítico da Península de Lisboa. As colecções do Museu Nacional de Arqueologia. O Arqueólogo Português, Supplemento 2. Lisboa.

Sastri, C. S. and Blondiaux, G. 1997: "Determination of fluorine by low energy deuteron activation: Comparison with a prompt nuclear technique". $\mathrm{Nu}$ clear Instruments and Methods in Physics Research Section B: Beams Interactions with Materials and Atoms 132 (3): 513-520.

Sastri, C. S.; Iyengar, V.; Blondiaux, G.; Tessier, Y.; Petri, H.; Hoffmann, P.; Aras, N. K.; Zaichick, V. and Ortner, H. M. 2001: "Fluorine determination in human and animal bones by particle-induced gamma-ray emission". 'Fresenius' Journal of Analytical Chemistry 370: 924-929.

Sastri, Ch. S.; Banerjee, A.; Sauvage, Th.; Courtois, B. and Schuhmacher, Th. 2013: "Fluorine determination in different types of ivory by PIGE technique". Journal of Radioanalytical and Nuclear Chemistry 295, 1. doi: 10.1007_s10967-012-2410-x.

Savelle, J. M. 2005: "The development of indigenous whaling: Prehistoric and historic contexts". In N. Kishigami and J. M. Savelle (eds.): Indigenous use and management of marine resources. Senri Ethnological Studies 67, National Museum of Ethnology. Osaka: 53-58.

Schreger, B. N. G. 1800: "Beitrag zur geschichte der Zähne”. Beitrage für die Zergliederungskunst 1: 1-7. Stuttgart.

Schuhmacher, Th. X. 2012: Die Elfenbeinobjekte des Chalkolithikums und derFrühen Bronzezeit auf der Iberischen Halbinsel. Interdisziplinäre Studien zu
Herkunft, Austausch, Verarbeitung und sozialer Bedeutung von Elfenbein. Iberia Archaeologica 16 (2). Darmstadt/Mainz.

Schuhmacher, Th. X. and Banerjee, A. 2011: "Pottwalelfenbein im chalkolithischen Portugal". Restaurierung und Archäologie 4: 107-119.

Schuhmacher, Th. X. and Banerjee, A. 2012: "Procedencia e intercambio de marfil en el Calcolítico de la Península Ibérica". In Actes del Congrés Internacional Xarxes al Neolític, Gavà-Barcelona, Rubricatum 5: 289-298.

Schuhmacher, Th. X. and Cardoso, J. L. 2007: "Ivory objects from the chalcolithic fortification of Leceia (Oeiras)". Estudos Arqueologicos de Oeiras 15: 95-118.

Schuhmacher, Th. X.; Cardoso, J. L. and Banerjee, A. 2009: "Sourcing African Ivory in Chalcolithic Portugal". Antiquity 83: 983-997.

Smith, A. B. and Kinahan, J. 1984: "The invisible whale". World Archaeology 16: 89-97.

Soares, J. 2003: Os hipogeus pré-históricos da Quinta do Anjo (Palmela) e as economias do simbólico. Museu de Arqueologia e Etnografia do Distrito de Setúbal. Setúbal.

Spindler, K. 1981: Cova da Moura. Die Besiedlung des Atlantischen KüstengebietesPortugals vom Neolithikum bis an das Ende der Bronzezeit. Madrider Beiträge 7. Mainz.

Uscatescu, A. 1992: Los botones de perforación en ' $V$ ' en la Península Ibérica y las Baleares durante la Edad de los Metales. Ed. Foro. Madrid.

Van der Merwe, N. J.; Lee-Throp, J. A.; Thackery, J. F.; Hall-Martin, A.; Kruger, F. J.; Coetzee, H. R.; Bell, H. V. and Lindeque, M. 1990: "Source-Area Determination of Elephant Ivory by Isotopic Analysis". Nature 346: 744-746.

Veiga, S. P. M. E. da 1886: Palaeoethnologia. Antiguidades monumentães do Algarve 1. Imprensa Nacional. Lisboa.

Veiga, S. P. M. E. da 1887: Palaeoethnologia. Antiguidades monumentães do Algarve 2. Imprensa Nacional. Lisboa.

Vogel, J. C.; Eglinton, B. and Auret, J. M. 1990: "Isotope Fingerprints in Elephant Bone and Ivory". $\mathrm{Na}$ ture 346: 747-749.

Witze, A. 2008: "Whaling scene found in 3000 year-old picture", Nature News (31 March 2008). doi:10.1038/news.2008.714.

Ziegler, J. F.; Biersack, J. P. and Ziegler, M. D. 2008: The stopping and range of ions in matter, SRIM. Chester, Maryland. 